\title{
In Memoriam Reender Kranenborg (1942-2020)
}

\author{
Hijme Stoffels*
}

'Neêrlands grootste sektenkenner' heb ik hem wel eens plagerig genoemd. Godsdienstwetenschapper Reender Kranenborg kon wel lachen om deze aanduiding, - het woord 'sekte' was not done in onze kringen -, maar hij was er heimelijk ook wel trots op. Hij was een pionier op het gebied van de wetenschappelijke bestudering van oosterse geloofsstromingen in het westen, destijds vaak aangeduid met de term 'New Age'. Vele jaren was hij de inspirerende en onvermoeibare eindredacteur van het halfjaarlijks tijdschrift Religieuze bewegingen in Nederland. Productief was hij als auteur van tal van boeken en artikelen over nieuwe en marginale religieuze stromingen en groeperingen.

Reender Kranenborg werd in 1971 na zijn studie theologie in Kampen predikant in de Gereformeerde Kerk van Gauw-Terzool in Friesland. Ondertussen werkte hij aan zijn proefschrift Zelfverwerkelijking, een omvangrijke studie naar de opkomst en invloed van oosterse religies in een westerse context, waarop hij in 1974 aan de Vrije Universiteit Amsterdam bij prof. Dick Mulder promoveerde. De toegang tot oosterse bewegingen liep vaak via drugsgebruik, zo was zijn stelling. De psychedelische ervaring, opgewekt door marihuana en LSD, leidde tot religieuze verlangens naar zelfverwerkelijking en bewustzijnsverruiming, die de westerse religie niet kon bevredigen. Die vond men wel in oosterse stromingen. Een jaar na zijn promotie werd Kranenborg predikant in Amsterdam en vanaf 1979 kreeg hij een parttime aanstelling als wetenschappelijk hoofdmedewerker bij het interfacultaire Instituut voor Godsdienstwetenschap aan de Vrije Universiteit, onder leiding van eerdergenoemde Dick Mulder.

In datzelfde jaar zag ik op het prikbord van de Theologische Faculteit een oproep voor een student-assistent, die zich met de opbouw en het beheer van een Documentatiecentrum Nieuwe religieuze bewegingen zou gaan bezighouden. Dat leek me een kolfje naar mijn hand en ik solliciteerde naar de job. Met licht spottende ogen over de rand van zijn brillenglazen kijkend testte Reender mijn kennis en motivatie. Het kwam goed. We mochten elkaar wel en hadden altijd veel gespreksstof.

\footnotetext{
* Hijme Stoffels is emeritus hoogleraar godsdienstsociologie aan de Vrije Universiteit Amsterdam.
} 
Er was in die jaren sprake van een grote honger naar informatie over goeroes, 'jeugdreligies' en opwekkingsbewegingen, zowel van oosterse als westerse snit. Jarenlang probeerden wij journalisten, docenten, scholieren en verontruste familieleden van min of meer objectieve informatie te voorzien over de Verenigingskerk, Transcendente Meditatie, Scientology, Hare Krishna, Bhagwan Shri Rajneesh, de Children of God, de Divine Light Mission en wat zich verder aan nieuwe religieuze bewegingen manifesteerde. Soms was er zelfs sprake van 'morele paniek' over het vermeende gevaar van nieuwe religies, onder meer gevoed door de collectieve zelfmoord van Jim Jones en zijn volgelingen in Brits Guyana (1979) en horrorverhalen in de vaderlandse pers. Dit resulteerde in een onderzoek van de Tweede Kamer naar de activiteiten van een aantal in Nederland opererende bewegingen. In dat kader togen Reender en ik eind 1981 naar het gebouw van de Tweede Kamer voor een ontmoeting met de Subcommissie sekten van de vaste Commissie voor de Volksgezondheid onder leiding van Erica Terpstra. Het werd een boeiende middag. Uiteindelijk kwam de commissie tot het oordeel dat nieuwe religieuze bewegingen in het algemeen geen groot gevaar vormden voor de geestelijke volksgezondheid (Witteveen 1984, 308).

Kranenborg had in 1980 het initiatief genomen tot het populair-wetenschappelijke tijdschrift Religieuze bewegingen in Nederland. Feiten en visies, dat zeker in de beginjaren gretig aftrek vond bij een geïnteresseerd publiek. "De religieuze kaart van Nederland is verwarrend en onoverzichtelijk geworden.”, zo schreef hij in de eerste aflevering $(1980,1)$. De redactie wilde zo objectief en zakelijk mogelijk over allerlei bewegingen en stromingen rapporteren. Daarnaast was er ook ruimte voor kritische analyse "op wetenschappelijke gronden en vanuit een christelijke visie.” $(1980,3)$ In dat laatste klonk de stem van de theoloog, die Reender al die jaren ook geweest is. Daarbij zocht hij als nuchtere en sceptische wetenschapper behoedzaam een weg tussen de onverholen afschuw van zelfbenoemde 'sektenbestrijders' enerzijds en de kritiekloze bewondering van volgelingen anderzijds, hetgeen hem niet altijd in dank werd afgenomen.

Het eerste nummer van Religieuze bewegingen bevatte al direct een zeer actuele analyse van zijn hand van Bhagwan Shri Rajneesh (later: Osho) en zijn beweging, die eind jaren zeventig, begin jaren tachtig veel opzien baarde en ook in Nederland aanhang verwierf. Na een schets van ontstaan en ontwikkeling van de beweging en een samenvatting van de visie van Bhagwan, kwam Kranenborg in het artikel tot een plaatsbepaling van deze beweging in en tegenover het hindoeïsme en andere religies. Tenslotte gaf hij een uitgebreide beoordeling van de zijns inziens dubieuze kanten van de beweging 
en haar leider. Hij stelde kritische vragen bij de persoonlijkheidscultus rond Bhagwan, de sterke psychische en sociale druk in de ashram, het gebrek aan nazorg en het ontbreken van een duidelijke ethiek (Kranenborg 1980). Zo zou Kranenborg nog vele artikelen en boeken schrijven over tal van religieuze bewegingen en verschijnselen, waarbij hij zich altijd uitstekend documenteerde en een uitvoerige, min of meer objectieve beschrijving gaf van leider(s), leer en praktijk, steevast gevolgd door een kritische beschouwing.

In de jaren negentig liep de publieke belangstelling in Nederland voor nieuwe religieuze bewegingen en daarmee ook het abonnee-aantal van het tijdschrift terug. In 1996 sloot de redactie de reeks toepasselijk af met een aflevering over 'Eindtijdbewegingen'. Kranenborg leverde zoals altijd een doorwrocht artikel af, dit keer over eindtijdverwachtingen binnen christendom en New Age (Kranenborg 1996).

Internationaal was Kranenborg actief binnen CESNUR, een internationaal netwerk van academici onder leiding van Massimo Introvigne, gewijd aan de bestudering van nieuwe religieuze bewegingen. Hij redigeerde enkele internationale bundels en publiceerde in bladen als Nova Religio, Exchange en Journal of Contemporary Religion.

In 1997 startte hij, samen met godsdienstsocioloog Jan Jonkers en historicus Gerard Hoekstra, de boekenserie Wegwijs over wereldreligies, religieuze stromingen en groeperingen. Hij publiceerde in deze reeks over Hindoeïsme (1997), Neohindoeïstische bewegingen in Nederland (2002) en Satanisme (2006). Daarnaast verschenen boeken waarin hij de relatie tussen de kerk en New Age bewegingen onderzocht, zoals Een nieuw licht op de kerk: bijdragen van nieuwe religieuze bewegingen voor de kerk van vandaag (1984) en New Age: visies vanuit het christelijk geloof (1993). Tevens verdiepte hij zich in moderne 'doorgevingen' van gene zijde, die bedoeld waren als aanvulling op of vervanging van de Bijbel (2004). Als nuchter en rationeel ingesteld mens moest hij daar weinig van hebben en hij stak zijn kritiek dan ook niet onder stoelen of banken. "Het zijn aardige dingen om te lezen, maar ik vraag me wel eens af: hoe krijg je het bij elkaar verzonnen?" (Trouw, 13 sept. 2002).

$\mathrm{Na}$ de ontmanteling van het Instituut voor Godsdienstwetenschap kwam Kranenborg in 1994 als universitair docent godsdienstwetenschap in dienst van de Theologische Faculteit van de Vrije Universiteit, alwaar hij als vanzelfsprekend het vak 'Nieuwe religieuze bewegingen' binnen de nieuwe opleiding Religie en Levensbeschouwing ging doceren. Ook na zijn pensionering in 2007 bleef hij nog enige jaren dit vak verzorgen. Daarna werd het allengs stiller. Ik kwam Reender nog wel een enkele keer tegen op de gangen van de faculteit, totdat ook dat niet meer gebeurde. De laatste periode van zijn 
en haar leider. Hij stelde kritische vragen bij de persoonlijkheidscultus rond Bhagwan, de sterke psychische en sociale druk in de ashram, het gebrek aan nazorg en het ontbreken van een duidelijke ethiek (Kranenborg 1980). Zo zou Kranenborg nog vele artikelen en boeken schrijven over tal van religieuze bewegingen en verschijnselen, waarbij hij zich altijd uitstekend documenteerde en een uitvoerige, min of meer objectieve beschrijving gaf van leider(s), leer en praktijk, steevast gevolgd door een kritische beschouwing.

In de jaren negentig liep de publieke belangstelling in Nederland voor nieuwe religieuze bewegingen en daarmee ook het abonnee-aantal van het tijdschrift terug. In 1996 sloot de redactie de reeks toepasselijk af met een aflevering over 'Eindtijdbewegingen'. Kranenborg leverde zoals altijd een doorwrocht artikel af, dit keer over eindtijdverwachtingen binnen christendom en New Age (Kranenborg 1996).

Internationaal was Kranenborg actief binnen CESNUR, een internationaal netwerk van academici onder leiding van Massimo Introvigne, gewijd aan de bestudering van nieuwe religieuze bewegingen. Hij redigeerde enkele internationale bundels en publiceerde in bladen als Nova Religio, Exchange en Journal of Contemporary Religion.

In 1997 startte hij, samen met godsdienstsocioloog Jan Jonkers en historicus Gerard Hoekstra, de boekenserie Wegwijs over wereldreligies, religieuze stromingen en groeperingen. Hij publiceerde in deze reeks over Hindoeïsme (1997), Neohindoeïstische bewegingen in Nederland (2002) en Satanisme (2006). Daarnaast verschenen boeken waarin hij de relatie tussen de kerk en New Age bewegingen onderzocht, zoals Een nieuw licht op de kerk: bijdragen van nieuwe religieuze bewegingen voor de kerk van vandaag (1984) en New Age: visies vanuit het christelijk geloof (1993). Tevens verdiepte hij zich in moderne 'doorgevingen' van gene zijde, die bedoeld waren als aanvulling op of vervanging van de Bijbel (2004). Als nuchter en rationeel ingesteld mens moest hij daar weinig van hebben en hij stak zijn kritiek dan ook niet onder stoelen of banken. "Het zijn aardige dingen om te lezen, maar ik vraag me wel eens af: hoe krijg je het bij elkaar verzonnen?" (Trouw, 13 sept. 2002).

$\mathrm{Na}$ de ontmanteling van het Instituut voor Godsdienstwetenschap kwam Kranenborg in 1994 als universitair docent godsdienstwetenschap in dienst van de Theologische Faculteit van de Vrije Universiteit, alwaar hij als vanzelfsprekend het vak 'Nieuwe religieuze bewegingen' binnen de nieuwe opleiding Religie en Levensbeschouwing ging doceren. Ook na zijn pensionering in 2007 bleef hij nog enige jaren dit vak verzorgen. Daarna werd het allengs stiller. Ik kwam Reender nog wel een enkele keer tegen op de gangen van de faculteit, totdat ook dat niet meer gebeurde. De laatste periode van zijn 
leven verbleef hij in een zorgcentrum in Amsterdam-Buitenveldert, op een steenworp afstand van de Vrije Universiteit. Hij overleed op 8 april 2020 op 77-jarige leeftijd. Vanwege de coronacrisis vond de begrafenis in Terzool in besloten kring plaats.

\section{Literatuur}

Kranenborg, R. (1974),

Zelfverwerkelijking. Oosterse religies binnen een westerse subkultuur, Kampen: Kok.

Kranenborg, R. (1977),

Transcendente meditatie: Verlangen naar zinvol leven en religie, Kampen: Kok.

Kranenborg, R. (1980),

Bhagwan Shri Rajneesh en zijn beweging, in: Religieuze bewegingen in Nederland, 1, 4-36.

Kranenborg, R. (eindred.) (1980-1996),

Religieuze bewegingen in Nederland. Feiten en visies.

Kranenborg, R. (1982),

Oosterse geloofsbewegingen in het Westen: Bhagwanbeweging, Hare Krishna gemeenschap, Transcendente Meditatie, Healthy-Happy-Holy-Organization, Divine Light Mission, Yoga, Verenigingskerk, Ede: Zomer en Keuning.

Kranenborg, R. (1984),

Een nieuw licht op de kerk? Bijdragen van nieuwe religieuze bewegingen voor de kerk van vandaag, 's-Gravenhage: Boekencentrum.

Kranenborg, R. (1989),

Reïncarnatie en christelijk geloof, Kampen: Kok.

Kranenborg, R. (1993),

New Age: visies vanuit het christelijk geloof, Amersfoort: De Horstink.

Kranenborg, R. (1996),

Berekeningen van het Einde. Apocalyptische berekeningen binnen christendom en New Age, in: Religieuze bewegingen in Nederland, 32, 1-40.

Kranenborg, R. (1997),

Hindoeïsme, Kampen: Kok.

Kranenborg, R. (2002),

Neohindoeistische bewegingen in Nederland: een encyclopedisch overzicht, Kampen: Kok.

Kranenborg, R. (2004),

De wonderbaarlijke avonturen van Jezus van Nazaret: over de waarde van 'hervonden manuscripten' en 'nieuwe openbaringen', Kampen: Ten Have. 
Kranenborg, R. (2006),

Satanisme, Kampen: Kok.

Mayer, J.-F. \& R. Kranenborg (eds.) (2004),

La naissance des nouvelles religions, Genève: Georg.

Rothstein, M. \& R. Kranenborg (eds.) (2003),

New religions in a postmodern world, Aarhus, Denmark: Aarhus University Press.

Witteveen, T. (1984),

Overheid en nieuwe religieuze bewegingen, 's-Gravenhage: Staatsuitgeverij. 